\title{
Mediterranean and Near East obsidian reference samples to establish artefacts provenance
}

Pasquale Avino ${ }^{1 *+}$ and Alberto Rosada ${ }^{2+}$

\begin{abstract}
Background: The commercial obsidian trade played an important role during Neolithic period. Its characteristics favoured the exchange network. In this way the Mediterranean area was fundamental. The availability of significant numbers of obsidian samples has allowed to improve the knowledge about the trade and commercial routes. Obsidian samples from the Mediterranean (Aegean, Flegrean, North Latium, Sicily, Sardinia) and Near East (Anatolia) areas were directly collected on the sites and considered as reference. Almost 30 elements were analyzed by Instrumental Neutron Activation Analysis (INAA).

Results: The approach based on the source discrimination analysis allowed to identify clearly different obsidian deposits, except the reference samples coming from Flegrean and Sicily areas, quite similar for their geochemical origin. The obtained data were used for assigning the provenance of 71 obsidian artefacts found during archaeological excavations in Tuscany. Two different groups were found: 16 artefacts were attributed to Sicily/Flegrean area whereas 55 items seemed to show a provenance from Aegean.
\end{abstract}

Conclusions: The results are important because they represents a confirmation about the hypothesis of the existence of a large exchange network in the Mediterranean area since 3000 B.C.

\section{Background}

Obsidian is a volcanic glass formed as an extrusive igneous rock $\left(\mathrm{SiO}_{2}\right.$ as main component ranging between $66 \%$ and $75 \%$ ) that was used by Neolithic people (around $10000-3500$ B.C.) as a raw material in the manufacture of stone tools such as weapons tips, knives, or other cutting tools through a sophisticated chopping elaboration. Basically, obsidian can be found in locations which have experienced rhyolitic eruptions such as the Middle East and the Mediterranean area.

The trade of obsidian has played an important role in ancient times: the characteristics of good storage and processing have facilitated the trade of this stone. It must be remembered that obsidian artefacts have also been found in sites remote from supply points, confirming the importance of this raw material and spread trades during prehistoric times. Several authors have attempted to understand the role that has had this level of trade in prehistoric societies [1-3]. In this scenario,

\footnotetext{
* Correspondence: p.avino@inail.it

${ }^{\dagger}$ Equal contributors

'DIPIA, INAIL settore Ricerca, via IV Novembre 144, Rome I-00187, Italy

Full list of author information is available at the end of the article
}

the Mediterranean area played a key role [4-7]. The largest deposits of obsidian found in this area come from the Italian islands of Lipari, Palmarola, Pantelleria and Sardinia. Briefly, some details on obsidian from these data are given below. Pantellerian obsidian, easily differentiable from the other central Mediterranean sources on a visual basis, is a $\mathrm{Na}$ - and $\mathrm{Fe}$-rich greenish opaque stone known as Pantellerite $[8,9]$. Detailed examination of prehistoric artefact assemblages has revealed at least two visual types of Lipari obsidian, one black and highly transparent, the other gray-banded, often with many spherulites present, suggesting that different obsidian outcrops might have different chemical fingerprints that would be useful for interpretation of prehistoric exploitation practices. About Sardinia deposits at least three groups (SA, SB, SC) are identified in early provenance studies on archaeological material [4]: deposit SA is along the Southern slope of Arci Mountain, deposit SB along the Western slope and deposit SC along the Eastern slope. Such obsidians appear very glassy obsidian, variable in transparency and sometimes with phenolcrystals up to $2 \mathrm{~mm}$ in diameter. Obsidian of type SA is fairly translucent, glassy, similar in appearance to that of 
Lipari; the obsidian of type SC is opaque, less glassy, similar to obsidian from Palmarola.

Until a few years ago it was not possible to define different markets for the various obsidian: this occurrence produced a great variability of obsidian and a difficult option to assign an exact provenance of an artifact from a specific area [10]. An important example is derived from the results of a study carried out on a mosaic of the Church of St. Juvenal in Umbria (Central Italy) [11]. In fact, the obsidian tesserae of the mosaic depicting the "Majestas Christi" in the Cathedral of Narni, come from the deposite Monte Arci, site C, in Sardinia: the peculiarity is that they have been found as reused material in such mosaic. Of course, this circumstance, very common in medieval artefacts, greatly complicates the dating of obsidian-crafted objects. If we add the existence of other smaller deposits in the Mediterranean area (e.g., Northern Latium and Campania in Italy), the ability to assign a precise provenance of obsidian in the Mediterranean is even more complicated.

Moreover, important deposits are also found in the area of the Near East, from the Aegean Sea to North-East Anatolia (Kars) and Armenia (Yerevan). Obsidian coming from this area is basically characterized by the presence of feldspar phenocrystals: two types of obsidian, one black and the other olive green, are also recognized. Under a microscope analysis the latter obsidian shows needle-like iso-oriented inclusions and opaque phenocrystals [12]. In Armenia, in particular, the existence of other obsidian outcrops is definitely known but the exact location is still unknown (e.g., obsidian raw materials collected in the districts of Kars and Erevan [13]).

Nowadays, the ability to analyze discrete quantities of obsidian from several sites allows us to describe the market flow at the time in a more exact and precise way, even reconstructing the different mechanisms of trade and transport used in different places and periods. In this context, this paper focusing on the obsidian reference samples coming from different deposits of the Mediterranean and the Near East areas, identifies a possible chemical fingerprint of distinction and applies this findings to 71 obsidian artefacts found during archaeological excavations in Tuscany for assigning the relative provenance.

\section{Experimental \\ Sampling}

The reference obsidian samples were directly collected in different deposits in Mediterranean and Near East areas where the obsidians were collected. In particular, obsidians of the Mediterranean area are from the Aegean Islands (Antiparos, Gyali and Milos), the Flegrean Islands (off the coast of Naples in southern Italy; Capri, Ischia, Procida Mount of Procida, Procida Punta della
Lingua, Palmarola), the Campania Region (Mondragone), the Northern Latium (Civita di Bagnoregio), the Eolie Islands (Lipari, Lipari Monte Pilato, Lipari Pomiciazzo, Vivara, Vulcano), the Pantelleria Island (Pantelleria, Porta Medaglia) and the Sardinia Island (Arci Mt.), whereas obsidians from the Near East (or Asia Minor) area are from Anatolia (Armenia, Erevan, Nemrut Dag, North Caucasus). On the other hand, 71 obsidian artefacts coming from archaeological excavations performed in Tuscany were analyzed by INAA. All the archaeological artefacts

\section{Table 1 Analytical nuclear data used in INAA}

\begin{tabular}{|c|c|c|c|c|c|c|}
\hline Radionuclide & Element & Half life & & $\begin{array}{l}\text { Y-Ray } \\
\text { used } \\
(\mathrm{keV})\end{array}$ & $\begin{array}{l}\operatorname{LOD}^{a} \\
\left(\mu g g^{-1}\right)\end{array}$ & Note \\
\hline${ }^{76} \mathrm{As}$ & As & 26.3 & $\mathrm{~h}$ & 559.2 & 0.008 & ${ }^{122} \mathrm{Sb}^{\mathrm{b}}$ \\
\hline${ }^{131} \mathrm{Ba}$ & $\mathrm{Ba}$ & 11.8 & $d$ & 496.3 & 10 & \\
\hline${ }^{82} \mathrm{Br}$ & $\mathrm{Br}$ & 35.87 & h & 776.6 & 0.02 & ${ }^{152} \mathrm{Eu}^{\mathrm{b}}$ \\
\hline${ }^{141} \mathrm{Ce}$ & $\mathrm{Ce}$ & 32.38 & $d$ & 145.4 & 0.01 & \\
\hline${ }^{58} \mathrm{Co}$ & $\mathrm{Ni}$ & 71.3 & d & 810.3 & 80 & $(n, p)^{c}$ \\
\hline${ }^{60} \mathrm{Co}$ & $\mathrm{Co}$ & 5.272 & y & 1332.5 & 0.0008 & \\
\hline${ }^{51} \mathrm{Cr}$ & $\mathrm{Cr}$ & 27.7 & $d$ & 320.0 & 0.09 & \\
\hline${ }^{134} \mathrm{Cs}$ & Cs & 2.062 & y & 795.7 & 0.003 & \\
\hline${ }^{152} \mathrm{Eu}$ & Eu & 12.7 & y & 1408.8 & 0.0002 & \\
\hline${ }^{59} \mathrm{Fe}$ & $\mathrm{Fe}$ & 45.1 & $d$ & 1099.2 & 5 & \\
\hline${ }^{181} \mathrm{Hf}$ & $\mathrm{Hf}$ & 42.5 & $d$ & 482.2 & 1 & \\
\hline${ }^{42} \mathrm{~K}$ & K & 12.36 & h & 1524.7 & 260 & \\
\hline${ }^{140} \mathrm{La}$ & La & 40.27 & $\mathrm{~h}$ & 1596.2 & 0.0005 & \\
\hline${ }^{24} \mathrm{Na}$ & $\mathrm{Na}$ & 15.02 & $\mathrm{~h}$ & 1368.6 & 2 & \\
\hline${ }^{147} \mathrm{Nd}$ & $\mathrm{Nd}$ & 11.06 & $d$ & 531.0 & 10 & \\
\hline${ }^{86} \mathrm{Rb}$ & $\mathrm{Rb}$ & 18.66 & $d$ & 1076.7 & 0.4 & \\
\hline${ }^{122} \mathrm{Sb}$ & $\mathrm{Sb}$ & 2.70 & $d$ & 564.0 & 6 & \\
\hline${ }^{124} \mathrm{Sb}$ & $\mathrm{Sb}$ & 60.9 & $d$ & 1690.7 & 0.01 & \\
\hline${ }^{46} \mathrm{SC}$ & Sc & 83.85 & $d$ & 889.2 & 0.0008 & \\
\hline${ }^{75} \mathrm{Se}$ & $\mathrm{Se}$ & 120.4 & d & 264.6 & 0.02 & ${ }^{182} \mathrm{Ta}^{\mathrm{b}}$ \\
\hline${ }^{153} \mathrm{Sm}$ & $\mathrm{Sm}$ & 1948 & y & 103.1 & 0.001 & \\
\hline${ }^{113} \mathrm{Sn}$ & Sn & 115.1 & $d$ & 391.1 & 40 & \\
\hline${ }^{85} \mathrm{Sr}$ & $\mathrm{Sr}$ & 64.0 & $d$ & 514.0 & 0.08 & $e^{+}+e^{-c}$ \\
\hline${ }^{182} \mathrm{Ta}$ & $\mathrm{Ta}$ & 115 & $d$ & 1221.3 & 0.5 & \\
\hline${ }^{160} \mathrm{~Tb}$ & $\mathrm{~Tb}$ & 72.1 & $d$ & 879.4 & 0.08 & \\
\hline${ }^{233} \mathrm{~Pa}$ & Th & 27.4 & $d$ & 311.8 & 0.2 & $\left(n, \gamma, \beta^{-}\right)$ \\
\hline${ }^{239} \mathrm{~Np}$ & U & 2.35 & $d$ & 277.6 & 0.2 & ${ }^{203} \mathrm{Hg}^{\mathrm{b}}{ }^{76} \mathrm{Se}^{\mathrm{b}}$ \\
\hline${ }^{187} \mathrm{~W}$ & W & 23.9 & $\mathrm{~h}$ & 687.7 & 0.1 & \\
\hline${ }^{175} \mathrm{Yb}$ & $\mathrm{Yb}$ & 4.19 & $d$ & 396.1 & 2 & \\
\hline${ }^{65} \mathrm{Zn}$ & $\mathrm{Zn}$ & 243.8 & $d$ & 1115.5 & 0.04 & ${ }^{46} S C^{b}$ \\
\hline${ }^{95} \mathrm{Zr}$ & $\mathrm{Zr}$ & 65.0 & $d$ & 756.6 & 80 & \\
\hline
\end{tabular}

Nuclear data (i.e., radioisotope from $(n, \gamma)$ reaction, half-life ( $h$ : hour; d: day; $y$ : year), peak energy, note) and LOD of each element investigated in this study (a: calculated according to ref. 15 and expressed as $\mu \mathrm{g} \mathrm{g}^{-1}$; b: interfering radionuclide; $c$ : other types of neutron reactions). 
studied are dated about $5000 \mathrm{BP}$ according to the not calibrated ${ }^{14} \mathrm{C}$ investigation.

\section{Obsidian sample analysis by INAA}

Obsidian samples and standards, weighing about $0.5 \mathrm{~g}$, put in nuclear-grade polyethene cylinders (Kartell, Milan, Italy), were irradiated in the rotatory rack "Lazy Susan" of the TRIGA Mark II RC-1 reactor (1 MW power) of the ENEA-Casaccia Laboratories under a neutron flux of $2.6 \times 10^{12} \mathrm{n} \mathrm{cm}^{-2} \mathrm{~s}^{-1}$. The flux stability (>99.8\%) was tested irradiating $\mathrm{Au}$ standards as flux monitor; the maximum irradiation temperature in the rotating rack reached $40^{\circ} \mathrm{C}$. The high integrated flux, i.e. $1.8 \times 10^{17} \mathrm{n} \mathrm{cm}^{-2}$, allowed to investigate elements whose $\gamma$-radioisotopes have half-life time ranging between 0.5 day and 15 years [14].

After irradiation, $\gamma$-ray spectrometry measurements of different durations were carried out using a Ge(HP) EG\&G Ortec (efficiency 23.1\%,peak-Compton ratio 58.3:1, FWHM
$1.70 \mathrm{keV}$ at $1332 \mathrm{keV}$ ) connected to a multi-channel analyzer equipped with software package (Ortec ADCAM Maestro II) for $\gamma$-spectra analysis.

Radionuclides characterized by gamma radioisotopes with half-life time ranging between 12 hours and 3 days, such as ${ }^{24} \mathrm{Na},{ }^{42} \mathrm{~K},{ }^{76} \mathrm{As},{ }^{82} \mathrm{Br},{ }^{122} \mathrm{Sb},{ }^{140} \mathrm{La},{ }^{147} \mathrm{Nd},{ }^{153} \mathrm{Sm}$, ${ }^{175} \mathrm{Yb},{ }^{187} \mathrm{~W}$ and ${ }^{239} \mathrm{~Np}$, were determined performing measurements of 1 hrs-long after 5 days from the end of the irradiation; a second series of measurements ( $24 \mathrm{hrs}-$ long) were performed after about 40 days of the end of the irradiation for determining radioisotopes with long half-life time such as ${ }^{46} \mathrm{Sc},{ }^{51} \mathrm{Cr},{ }^{58} \mathrm{Co},{ }^{59} \mathrm{Fe},{ }^{60} \mathrm{Co},{ }^{65} \mathrm{Zn}$, ${ }^{75} \mathrm{Se},{ }^{86} \mathrm{Rb},{ }^{85} \mathrm{Sr},{ }^{86} \mathrm{Rb},{ }^{95} \mathrm{Zr},{ }^{113} \mathrm{Sn},{ }^{124} \mathrm{Sb},{ }^{131} \mathrm{Ba},{ }^{134} \mathrm{Cs}$, ${ }^{141} \mathrm{Ce},{ }^{147} \mathrm{Nd},{ }^{152} \mathrm{Eu},{ }^{160} \mathrm{~Tb},{ }^{181} \mathrm{Hf},{ }^{182} \mathrm{Ta}$ and ${ }^{233} \mathrm{~Pa}$. Overall the measurements, 30 elements were investigated: As, Ba, Br, Ce, Co, Cr, Cs, Eu, Fe, Hf, K, La, Na, Nd, Ni, $\mathrm{Rb}, \mathrm{Sb}, \mathrm{Sc}, \mathrm{Se}, \mathrm{Sm}, \mathrm{Sn}, \mathrm{Sr}, \mathrm{Ta}, \mathrm{Tb}, \mathrm{Th}, \mathrm{U}, \mathrm{W}, \mathrm{Yb}, \mathrm{Zn}$ and Zr. Table 1 shows the nuclear data and Limits of

Table 2 Precision and accuracy of the INAA measurements

\begin{tabular}{|c|c|c|c|c|c|c|}
\hline \multirow[t]{2}{*}{ Element } & \multirow{2}{*}{$\begin{array}{l}\text { USGS GRX-4 } \\
\text { Found }\end{array}$} & \multirow[b]{2}{*}{ Certified } & \multirow[b]{2}{*}{ Z-score } & \multirow[t]{2}{*}{ USGS G-2 } & & \multirow[b]{2}{*}{ Z-score } \\
\hline & & & & & & \\
\hline As & $104 \pm 4(3.8)$ & $98 \pm 10$ & $-1,5$ & - & - & \\
\hline $\mathrm{Ba}$ & & $1350 \pm 330$ & & $1865 \pm 19$ & $1880 \pm 23$ & 1,6 \\
\hline $\mathrm{Ce}$ & $69 \pm 7$ & $114 \pm 8$ & 6,4 & $147.7 \pm 9.8$ & $160 \pm 10$ & 1,3 \\
\hline Co & $12.4 \pm 0.7$ (5.6) & $16 \pm 2$ & 5,1 & $4.35 \pm 0.29$ & $4.6 \pm 0.7$ & 0,9 \\
\hline $\mathrm{Cr}$ & $64 \pm 14$ (21.9) & $64 \pm 10$ & 0,0 & $9.81 \pm 0.51$ & - & \\
\hline Cs & $2.8 \pm 0.1$ (3.6) & $3 \pm 1$ & 2,0 & $1.55 \pm 0.28$ & $1.34 \pm 0.16$ & $-0,8$ \\
\hline $\mathrm{Eu}$ & $1.4 \pm 0.2(14.3)$ & $1.6 \pm 0.1$ & 1,0 & $1.41 \pm 0.05$ & $1.40 \pm 0.12$ & $-0,2$ \\
\hline Fe (\%) & $3.02 \pm 0.02(0.7)$ & $2.97 \pm 0.43$ & $-2,5$ & - & - & \\
\hline $\mathrm{Hf}$ & & $8.0 \pm 0.5$ & & $8.27 \pm 0.61$ & $7.9 \pm 0.7$ & $-0,6$ \\
\hline K (\%) & $4.2 \pm 0.1(2.4)$ & $4.3 \pm 0.6$ & 1,0 & - & - & \\
\hline La & $65 \pm 12(18.5)$ & $64 \pm 5$ & $-0,1$ & $85.2 \pm 5.3$ & $89 \pm 8$ & 1,2 \\
\hline $\mathrm{Na}$ & $5080 \pm 42(0.8)$ & $5300 \pm 300$ & 5,2 & - & - & \\
\hline $\mathrm{Nd}$ & - & - & & $57.3 \pm 2.8$ & $55 \pm 6$ & $-0,8$ \\
\hline $\mathrm{Ni}$ & $40.2 \pm 1.0(2.5)$ & $38 \pm 4$ & $-2,2$ & - & - & \\
\hline $\mathrm{Rb}$ & $166 \pm 7(4.2)$ & $174 \pm 7$ & 1,1 & $165 \pm 7$ & $170 \pm 3$ & 0,7 \\
\hline $\mathrm{Sb}$ & $5.2 \pm 0.2(3.8)$ & $4.4 \pm 0.8$ & $-4,0$ & - & - & \\
\hline Sc & & $8.3 \pm 0.4$ & & $3.7 \pm 0.3$ & $3.5 \pm 0.4$ & $-0,7$ \\
\hline Se & $8.2 \pm 0.2(2.4)$ & $6.0 \pm 0.5$ & $-11,0$ & - & $(0.07)$ & \\
\hline Sm & $6.3 \pm 0.1(1.6)$ & $6 \pm 1$ & $-3,0$ & $7.14 \pm 0.24$ & $7.2 \pm 0.7$ & 0,3 \\
\hline $\mathrm{Sr}$ & & $220 \pm 30$ & & $503 \pm 32$ & $478 \pm 2$ & $-0,8$ \\
\hline $\mathrm{Ta}$ & - & $0.77 \pm 0.07$ & & $0.974 \pm 0.091$ & $(0.5)$ & $-5,2$ \\
\hline Th & $21.1 \pm 5.9$ & $22 \pm 2$ & 0,2 & $25.0 \pm 1.4$ & $25 \pm 2$ & 0,0 \\
\hline$U$ & $6.13 \pm 2.82$ & $6.42 \pm 0.25$ & 0,1 & - & - & \\
\hline $\mathrm{Yb}$ & $1.9 \pm 0.2(10.5)$ & $1.8 \pm 0.1$ & $-0,5$ & $0.935 \pm 0.126$ & $0.8 \pm 0.2$ & $-1,1$ \\
\hline $\mathrm{Zn}$ & $60 \pm 9(15.0)$ & $64 \pm 10$ & 0,4 & $95 \pm 11$ & $86 \pm 8$ & $-0,8$ \\
\hline $\mathrm{Zr}$ & & $200 \pm 40$ & $-1,5$ & $289 \pm 22$ & $309 \pm 35$ & 0,9 \\
\hline
\end{tabular}

Analytical comparison (mean \pm s.d.; $\mu \mathrm{g} \mathrm{g}^{-1}$, except\% for Fe and $\mathrm{K}$ ) of USGS GRX-4 standard. In brackets are reported the coefficients of variation, CVs (\%), calculated as ratio between standard deviation and mean value $\times 100$. 
Detection (LODs) about the radioisotopes considered in this study [15].

Before performing analyses, the gamma detector was calibrated. In particular, energy and efficiency calibrations were obtained by means of calibrated sources such as multi-gamma radioisotopes, MRL1654 and MRL1655, from National Metrology Institute of Ionizing Radiations (INMRI, Italy), and single-gamma radioisotope, ${ }^{152} \mathrm{Eu}$, from Comité a l'Energie Atomique (CEA, France). For INAA analysis, primary and secondary standards were irradiated and measured in the same conditions described above. A mixture (ranging between 10-200 $\mu$ g of single element; each solution was obtained by dilution from $1 \mathrm{mg} \mathrm{mL}{ }^{-1}$ of mother solution of each one) of primary standards (Carlo Erba, Milan, Italy) was used. On the other hand, secondary standards were USGS GRX-4 (i.e., rock) and USGS G-2 (i.e., granite) (United States Geochemical Survey). The uncertainty of the methodology was tested measuring the secondary standards with solution of primary standards at different concentrations; the repeatability of measurements on obsidian matrix was tested by analyzing seven times, at different cooling times and with different measurement times, an obsidian sample coming from the Procida deposit. Finally, interferences due to the formation of radioisotopes measured as fission products $\left({ }^{95} \mathrm{Zr}, 6.50 \%\right.$; ${ }^{134} \mathrm{Cs}, 0.028 \%$; ${ }^{140} \mathrm{La}, 6.30 \%$; ${ }^{141} \mathrm{Ce}$, $5.78 \% ;{ }^{147} \mathrm{Nd}, 2.30 \% ;{ }^{153} \mathrm{Sm}, 0.27 \%$ ), have been evaluated and subtracted irradiating pure primary uranium standards.

\section{Results and discussion}

Importance of nuclear analytical technique on the matrix Among various possible analytical methods for the characterization of minor elements in obsidian, we have chosen a nuclear analytical technique known as Instrumental Neutron Activation Analysis (INAA). This technique allows to both analyze a very large number of elements (theoretically almost 70 natural elements of the Periodic Table; more realistically about 40 elements) with very good limits of detection (LODs), sensitivity and accuracy [16-29]. About the precision and accuracy of measurements performed on the standard involved in this study, all the found data for the standards are in agreement with the certified values. Table 2 shows the comparison between the determined concentrations and certified concentrations for the USGS GRX-4 and G-2 standards [30]. As it can be seen, the difference between the two data-set is good for almost all elements [31]. The accuracy can be considered satisfactory, being for most elements in the range of $\pm 10 \%$ of the reference values; a good precision has also been obtained in most cases.

An important point of this study was to evaluate the applicability of the nuclear analytical method to obsidian samples. In this way, an obsidian sample collected in an
Italian deposit (i.e. Procida Mt. in Gulf of Naples) was subjected to neutron irradiation: seven $\gamma$-spectrometry measurements were carried out at different cooling times and with different measurement times for determining the repeatability of the measurements in such matrix. Table 3 shows the results obtained for this task. As it can be seen, the CV\% is always below 10\%: in particular, it ranges between $0.7 \%$ (Ce and $\mathrm{U}$ ) and $5.3 \%(\mathrm{Sb})$ for almost all the elements except As (8.5\%), Co (8.1\%) and $\mathrm{Cr}$ (8.6\%). This understanding allows us to consider the whole analytical procedure used to be effective for the study of artefacts made of obsidian and coming from different deposits. In fact, the main elements to be taken in consideration for right assignment of the obsidian artefact provenance, is based on the content levels of some elements difficult to be determined (e.g., the source discrimination equation requires levels of Sc, Cs, Ta, Rb, Th, La, Ce).

Table 4 shows the levels of the trace elements determined in the obsidian samples collected in different

Table 3 Repeatability INAA measurements in obsidian matrix

\begin{tabular}{|c|c|c|c|c|c|}
\hline & Mean & St. Dev. & Min & Max & CV\% \\
\hline As & 23.3 & 2.0 & 21.5 & 26.1 & 8.5 \\
\hline $\mathrm{Ba}$ & 330 & 8 & 319 & 339 & 2.5 \\
\hline $\mathrm{Ce}$ & 211 & 2 & 209 & 212 & 0.7 \\
\hline Co & 1.36 & 0.11 & 1.23 & 1.51 & 8.1 \\
\hline $\mathrm{Cr}$ & 0.845 & 0.073 & 0.710 & 0.982 & 8.6 \\
\hline Cs & 18.8 & 0.4 & 18.2 & 19.1 & 2.0 \\
\hline $\mathrm{Eu}$ & 2.03 & 0.07 & 1.92 & 2.11 & 3.4 \\
\hline $\mathrm{Fe}$ & 24193 & 336 & 23690 & 24646 & 1.4 \\
\hline $\mathrm{Hf}$ & 11.2 & 0.5 & 10.4 & 11.8 & 4.7 \\
\hline La & 33.4 & 0.7 & 32.1 & 34.0 & 2.1 \\
\hline $\mathrm{Nd}$ & 1048 & 19 & 1027 & 1069 & 1.8 \\
\hline $\mathrm{Rb}$ & 276 & 11 & 264 & 291 & 4.1 \\
\hline $\mathrm{Sb}$ & 2.85 & 0.15 & 2.65 & 3.02 & 5.3 \\
\hline Sc & 2.26 & 0.11 & 2.09 & 2.32 & 4.9 \\
\hline Se & 6.20 & 0.19 & 6.07 & 6.42 & 3.1 \\
\hline Sm & 12.4 & 0.30 & 10.0 & 10.5 & 2.4 \\
\hline $\mathrm{Sr}$ & 300 & 8 & 292 & 310 & 2.5 \\
\hline $\mathrm{Ta}$ & 3.41 & 0.07 & 3.27 & 3.46 & 2.0 \\
\hline Th & 31.7 & 0.8 & 30.3 & 32.3 & 2.5 \\
\hline U & 6.81 & 0.04 & 6.76 & 6.85 & 0.7 \\
\hline $\mathrm{Yb}$ & 4.97 & 0.11 & 4.83 & 5.07 & 2.2 \\
\hline $\mathrm{Zn}$ & 71.0 & 2.3 & 67.1 & 73.8 & 3.2 \\
\hline $\mathrm{Zr}$ & 421 & 12 & 401 & 429 & 2.9 \\
\hline
\end{tabular}

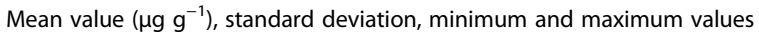
( $\mu \mathrm{g} \mathrm{g-1)}$ along with the Coefficient of Variation (CV\%) obtained analyzing the same obsidian sample (deposit in Procida Mt. in Gulf of Naples) by means of 7 $\mathrm{\gamma}$-spectrometry measures. 
Table 4 Trace element composition of obsidians from Mediterranean and Near East areas

\begin{tabular}{|c|c|c|c|c|c|c|}
\hline & Mediterranean are & & & & & Near East \\
\hline & Aegean Islands & Flegrean Islands & Civita di Bagnoregio & Eolie Islands & Sardinia Island & North Caucasus \\
\hline As & $7.71(4.31-8.82)$ & $21.9(7.24-36.4)$ & $24.9(22.0-29.5)$ & $18.1(7.26-35.3)$ & $12.3(11.4-13.2)$ & $12.6(3.43-19.5)$ \\
\hline $\mathrm{Ba}$ & $542(287-719)$ & $298(17.3-554)$ & $613(527-682)$ & $206(26.0-562)$ & 271 (254-288) & 331 (33.0-646) \\
\hline $\mathrm{Ce}$ & $46.2(28.6-56.6)$ & $170(88.4-225)$ & 115 (95.2-129) & $161(76.3-423)$ & $42.1(37.1-7.1)$ & 105 (35.9-293) \\
\hline Co & $8.01(7.31-8.53)$ & $0.927(0.151-1.51)$ & $11.8(11.5-12.0)$ & $1.27(0.201-7.84)$ & $2.97(2.91-3.02)$ & $0.311(0.062-0.590)$ \\
\hline $\mathrm{Cr}$ & $16.3(0.53-47.0)$ & $1.22(0.713-2.13)$ & $98.2(94.8-100)$ & $11.5(0.763-61.4)$ & 241 (223-265) & $1.27(0.464-3.60)$ \\
\hline Cs & 7.99 (5.33-9.54) & $27.5(13.6-44.1)$ & 18.4 (18.3-18.6) & $22.4(2.99-52.5)$ & $4.57(4.53-4.60)$ & $13.6(5.19-23.0)$ \\
\hline $\mathrm{Eu}$ & $0.568(0.271-0.813)$ & $1.24(0.060-2.09)$ & $1.58(1.52-1.64)$ & $0.787(0.082-4.16)$ & $0.332(0.312-.345)$ & $0.685(0.250-1.61)$ \\
\hline $\mathrm{Fe} \%$ & $1.52(0.65-1.99)$ & $1.88(0.98-2.44)$ & $3.86(3.82-3.98)$ & $1.89(0.967-6.25)$ & $1.39(1.37-1.4)$ & $1.78(0.61-4.94)$ \\
\hline $\mathrm{Hf}$ & $4.59(2.30-7.47)$ & $12.3(9.01-20.5)$ & $6.23(6.06-6.32)$ & $14.0(6.81-57.4)$ & 7.07 (6.95-7.26) & $14.1(3.56-41.7)$ \\
\hline K\% & $3.34(2.10-3.99)$ & $6.99(6.09-7.58)$ & $1.98(1.89-2.16)$ & $5.16(4.17-6.67)$ & $4.71(4.69-4.73)$ & $4.32(3.24-5.79)$ \\
\hline La & $12.0(11.7-13.9)$ & $27.4(20.9-34.0)$ & 19.9 (19.4-20.8) & $30.2(15.4-84.6)$ & $7.80(7.57-8.03)$ & $10.4(7.00-13.2)$ \\
\hline $\mathrm{Na} \%$ & $2.11(1.86-2.52)$ & $2.48(1.86-3.24)$ & $0.723(0.689-0.768)$ & $2.66(1.06-5.99)$ & $2.43(2.22-2.64)$ & $2.32(1.87-3.12)$ \\
\hline $\mathrm{Nd}$ & $231(193-266)$ & $618(25.0-1162)$ & $583(524-624)$ & $572(52.0-2847)$ & $361(346-376)$ & $444(17.2-1730)$ \\
\hline $\mathrm{Ni}$ & $12.6(4.70-23.0)$ & $11.1(4.60-19.3)$ & $51.1(47.4-55.9)$ & $12.4(.20-33.3)$ & $116(113-121)$ & $14.2(5.10-39.0)$ \\
\hline $\mathrm{Rb}$ & $126(84.4-161)$ & $324(233-434)$ & 217 (215-219) & $308(191-460)$ & $248(245-251)$ & $218(135-281)$ \\
\hline $\mathrm{Sb}$ & $0.752(0.381-1.28)$ & $0.842(0.142-1.57)$ & $0.703(0.410-1.13)$ & $0.707(0.313-1.63)$ & $1.44(1.41-1.46)$ & $0.579(0.210-1.22)$ \\
\hline Sc & $3.92(1.62-6.13)$ & $2.15(1.71-2.47)$ & $14.3(14.0-14.6)$ & $2.65(1.25-8.54)$ & $4.77(4.69-4.85)$ & $2.87(1.03-3.77)$ \\
\hline Se & $2.25(1.89-2.88)$ & $7.23(5.40-11.0)$ & $1.88(0.1 .71-2.00)$ & $8.77(2.85-44.5)$ & 7.49 (7.07-7.92) & $6.21(3.19-11.0)$ \\
\hline Sm & $3.11(2.59-4.11)$ & $9.90(7.12-14.0)$ & $8.02(7.52-8.43)$ & $10.7(5.95-37.5)$ & $6.16(6.04-6.27)$ & $7.74(1.92-22.1)$ \\
\hline Sr & 100 (6.60-186) & $93.3(4.30-294)$ & $518(454-580$ & $26.9(3.90-175)$ & $9.15(8.50-9.80)$ & $16.4(7.90-28.0)$ \\
\hline Ta & $0.998(0.392-1.49)$ & $4.09(3.18-6.05)$ & $1.06(1.03-1.12)$ & $4.88(2.05-24.7)$ & $3.86(3.84-3.88)$ & $3.45(2.22-5.61)$ \\
\hline Th & $12.3(4.65-16.5)$ & $40.1(23.3-58.9)$ & $23.6(23.2-23.9)$ & $46.7(20.5-71.0)$ & $16.2(16.0-16.4)$ & $22.5(16.8-32.7)$ \\
\hline U & $3.33(1.45-4.70)$ & $21.6(6.76-62.9)$ & $3.92(3.85-3.99)$ & $14.8(4.55-30.1)$ & $5.30(5.19-5.41)$ & $10.1(8.77-13.5)$ \\
\hline W & $148(10.0-300)$ & 305 (59.0-592) & $184(172-192)$ & $310(174-580)$ & 185 (175-194) & $197(136-279)$ \\
\hline $\mathrm{Yb}$ & $1.85(1.13-2.61)$ & $5.00(3.43-7.01)$ & $1.01(2.50-2.96)$ & $5.67(2.37-16.7)$ & $2.78(2.75-2.89)$ & $5.53(1.93-15.3)$ \\
\hline $\mathrm{Zn}$ & $34.9(20.2-49.1)$ & $59.1(15.2-114)$ & $77.1(72.3-80.6)$ & $77.4(32.8-402)$ & $406(384-429)$ & $81.3(35.7-217)$ \\
\hline $\mathrm{Zr}$ & $142(79.5-228)$ & 435 (285-696) & $212(211-214)$ & 441 (202-1793) & $193(185-200)$ & $439(136-1214)$ \\
\hline
\end{tabular}

Mean element levels along maximum and minimum values of obsidian collected in different well-defined deposits and analyzed by INAA ( $\mu \mathrm{g} \mathrm{g}^{-1}$, except Fe, $\mathrm{K}$ and $\mathrm{K}$ expressed as\%).

deposits located in the Mediterranean and Near East areas. First of all, $\mathrm{Sn}$ and $\mathrm{Tb}$, not reported, are always below the Limits of Detection $\left(40 \mu \mathrm{g} \mathrm{g}^{-1}\right.$ and $\left.0.08 \mu \mathrm{g} \mathrm{g}^{-1}\right)$ (see Table 1) whereas few elements show values below LODs in some specific deposits (i.e., $\mathrm{K}$ in Ischia; $\mathrm{Ba}$ and $\mathrm{Ni}$ in Procida Punta della Lingua; Ni in Vivara and Vulcano; Se in Vivara). It is interesting to note how the mean level of each element is quite different among the deposits whereas in some cases there are similar data (e.g., $\mathrm{Na}$ is quite similar for all the deposits, except for Civita di Bagnoregio). These data are important to serve as references for the provenance attribution of archaeological samples. In fact, the chemical resolution is fundamental in the characterization of the obsidian sources. The chemical characterization performed by INAA allowed to determine a lot of trace elements [3]. For instance, as just reported below, obsidian samples collected in the Flegrean Islands come from 4 different deposits located in different points of the archipelagos: the availability of trace element data gives the chance to identify the different obsidian sources. Bi-plot figures have been used for this aim. Figure 1 shows such plots [32]: in particular, Figure 1a shows the deposit grouping analyzing $\mathrm{Sr}$ vs $\mathrm{Zr}$ data whereas Figure $1 \mathrm{~b}$ analyzing Co vs La. It is interesting to note that the two plots are quite similar but some focal points can be evidenced. Firstly, the Figure 1a showing the plot $\mathrm{Sr} / \mathrm{Zr}$, manages to differ 4 different deposits in the Sicily Island (Balata dei Turchi; Vivara; Porta Medaglia SO; Incaldana), 2 deposits in the Flegrean Islands (Capri, Ischia and Monte di Procida; Procida Punta Lingua) and 1 deposit in 


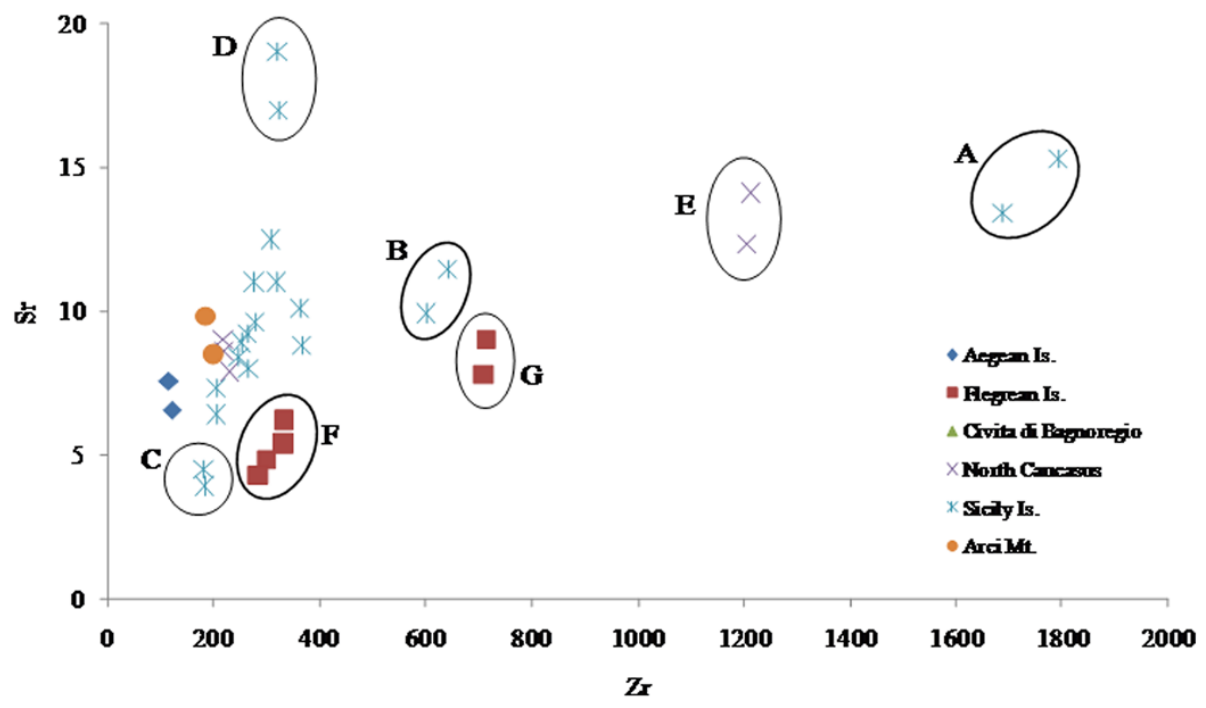

b

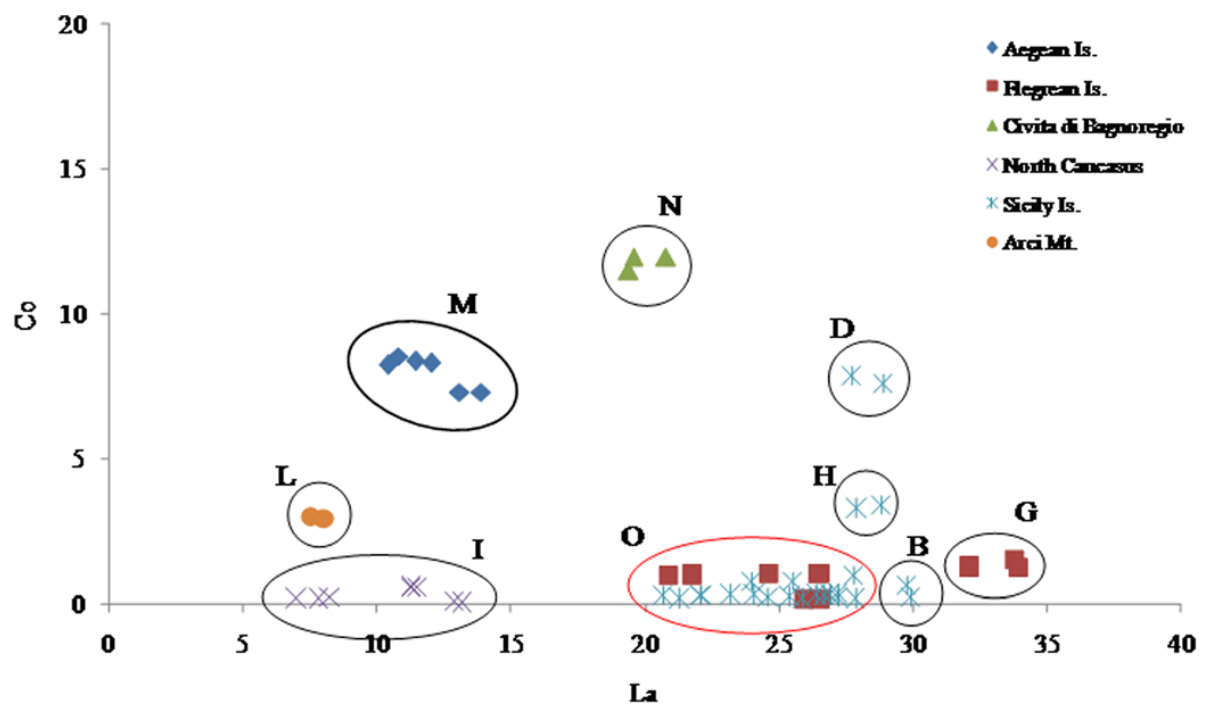

Figure 1 Identification of obsidian sub-deposits from which the samples used as reference were collected. Bi-plots (1a: Zr vs Sr; 1b: La vs Co) of the element grouping showing the sub-deposits (A: Sicily Is. Balata dei Turchi; B: Sicily Is. Vivara; C: Sicily Is. Porta Medaglia; D: Sicily Is. Incaldana; E: Near East Nemrut Dag; F: Flegrean Is. Capri, Ischia and Monte di Procida; G: Flegrean Is. Procida Punta Lingua; H: Sicily Is. Arivito; I: North Caucasus; L: Arci Mt.; M: Aegean Is.; N: Civita di Bagnoregio; O: Flegrean Is. and Sicily Is.).

the Near East (Nemrut Dag) whereas it does not able to differ deposits from Aegean Islands, Sardinia Island and some deposits located in Sicily (Lipari; Lipari Monte Pilato; Lipari Pomiciazzo; Vulcano; Palmarola; Pantelleria; Porta Medaglia) and Near East (Armenia; Erevan; North Caucasus). On the other hand, Figure 1b showing the plot $\mathrm{Co} / \mathrm{La}$, is able to solve some other deposits but the samples coming from the Flegrean Is. (except Procida Punta Lingua) and Sicily (except Vivara, Incaldana and Arivito) seems to show a same pattern making difficult an exact assignment of artefacts to such areas. For avoiding similar problems as well as analytical difficulties (e.g., for reducing the uncertainties due to variation in counting geometry, widely varying shape and mass of the sample) we followed the Aspinall protocol [33]. Although the number of samples is small (like the situation described in that paper), the application of source discrimination approach in relation to the Sc (considered as internal standard due to its high accuracy in the determination) theoretically also allows to identify 
very close deposits. For calculating the source discrimination we used the following formula [33]:

$$
\frac{1}{\mathrm{Sc}}\left(\mathrm{Cs}+\mathrm{Ta}+\frac{\mathrm{Rb}}{100}+\frac{\mathrm{Th}+\mathrm{La}+\mathrm{Ce}}{10}\right)
$$

Figure 2 shows the relative plot: all the deposits are almost well-separated (i.e. North Caucasus, Arci Mt., Civita di Bagnoregio, Aegean Is., 2 deposits in Sicily), whereas the samples coming from both the Flegrean Is. and some deposits from Sicily show the same pattern. This last analysis based on the trace element data determined with high accuracy and precision (due to the nuclear analytical technique used), allows us to assign the area of influence to each obsidian sample. As it can be seen, the obsidians coming the Near East are different from the obsidians coming from the Mediterranean area whereas obsidians from this area is not easy to differentiate. In particular, even if obsidians from Arci Mt., Civita di Bagnoregio (North Latium, Italy) and Aegean Is., make well-defined clusters, it cannot say the same thing for the Sicily and Flegrean obsidians. This suggests some other considerations about the ores in those areas: the two areas, i.e. the Flegrean area located in region Campania (South Italy) and the Sicily, are geochemically quite similar [34] whereas obsidians from North Latium (Avino P, Capannesi G, Rosada A, Manigrasso M: Classification of an area as metallogenic province: environmental importance and problems, submitted, 2014) and Sardinia (Arci Mt.) [35] are totally different, confirming as reported in literature.

\section{Analysis of obsidian-made artefacts}

Figure 3 shows examples of the 71 obsidian artefacts coming from the archaeological excavations performed in Tuscany. Table 5 shows the trace element data (column "all data") for all the artefacts investigated. Basically, the overall variability of the elements (expressed as CV\%) ranges between 11\% (Hf) and 166\% (Sb) (average 53\%), except for $7.5 \%(\mathrm{Zn})$, i.e. 1 of 31 elements show a significant variability whereas in the obsidian samples collected directly on site 8 of 27 elements (such as Sr, Ta Th, U, W, $\mathrm{Yb}, \mathrm{Zn}, \mathrm{Zr}$ ) report a CV\% below $10 \%$. According these data our hypothesis was of obsidian artefacts from different provenance, so we decided to apply the source discrimination approach to these samples using the previous obsidian samples as reference. The elements $\mathrm{Ce}, \mathrm{Cs}, \mathrm{La}$, $\mathrm{Rb}, \mathrm{Sc}, \mathrm{Ta}$ and $\mathrm{Th}$, are sufficient to separate the obsidian artefacts in different groups with high probability: Figure 4 shows the source discrimination approach applied to all the data. Two different groups (\#1 and \#2) can be well-recognized and divided according the sub-deposits previously identified. The samples owning to group \#1 (16 samples) are attributed to Sicily or Flegrean Is. provenance whereas the samples of group \#2 (55 samples) are definitely attributed to Agean Is. provenance. Theoretically, these considerations would be prudentially drawn and subjected to large uncertainty. Of course, the use of statistical methods similar to those involved in provenance characterization and quality control of the goods, increases the quality and gives high assurance on the results obtained. In this case, the availability of reference samples investigated and analyzed in the same conditions, allows us to extrapolate almost certain considerations on provenance of the obsidian artefacts found in the archaeological excavation.

This understatement confirms previous hypotheses [36] about the presence of a large network of exchange between the Aegean and the Mediterranean in the Third

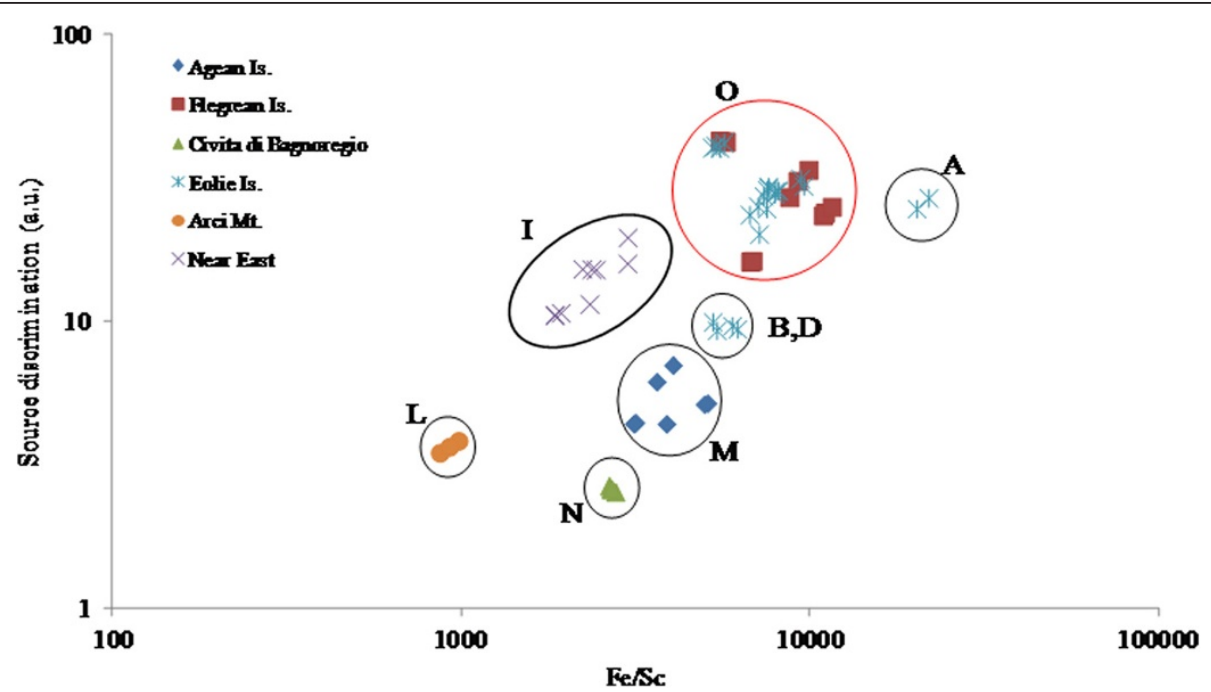

Figure 2 Source discrimination vs. Fe/Sc plot of reference obsidian sample. Multiple regression analysis: plot of the discrimination factor vs $\mathrm{Fe} / \mathrm{Sc}$ abundance ratio of the obsidian samples collected directly on the deposits and considered as reference in this study. 


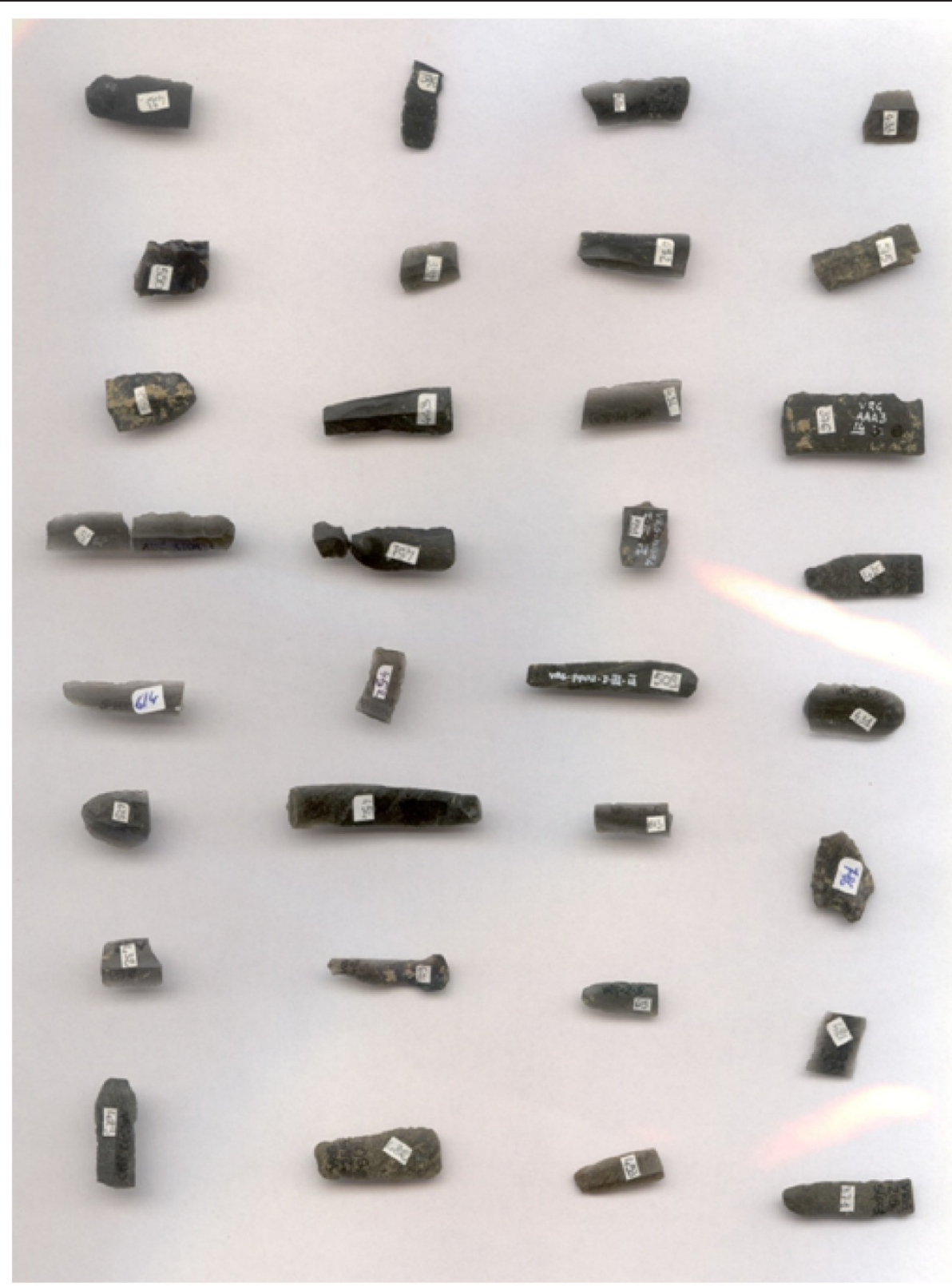

Figure 3 Formal obsidian tools from a site in Tuscany (3000 B.C.) Some obsidian artefacts found during archaeological excavations in Tuscany (Italy). The artefacts date back to 3000 B.C. according to the ${ }^{14} \mathrm{C}$ investigation.

Millennium B.C., a period of significant developments and rapid progress throughout the Mediterranean (and Aegean particularly). The archaeologists define the directionality of exchanges in terms of the presence or absence of objects from one area to the other. Our attention is pointed out on the 55 samples (group \#2) coming from Aegean area. In fact, it is almost understandable the presence of obsidian artefacts (group \#1) from Sicily/Flegrean areas whereas it is quite interesting the presence of obsidian artefacts made by material coming from East Mediterranean area (also considering the large availability of such substance in Italy). But, the distribution of imported objects and the influences in the Near East and Italy suggests that both networks were unidirectional and directed towards the Aegean. To the West contacts seem to have been unidirectional: from the Aegean to Italy, Sicily and Sardinia. The network consisted of exchange of material goods with the East and those exchanges relied either on freelance trade of ivory and, presumably, perishable goods, or random exchange of prestige gifts [36].

\section{Conclusions}

The availability of reference samples in heritage studies is quite important. Further, the obsidian reference items 
Table 5 Trace element composition of obsidian artefacts found in the Tuscany archaeological site

\begin{tabular}{|c|c|c|c|}
\hline & All data (71 samples) mean (min-max) & Group \#1 (16 samples) mean \pm st. dev. (CV\%) & Group \#2 (55 samples) mean \pm st. dev. (CV\%) \\
\hline As & $5.92(0.770-19.1)$ & $14.8 \pm 3.3(21.9)$ & $1.22 \pm 0.35(28.8)$ \\
\hline $\mathrm{Ba}$ & $931(114-3813)$ & $1090 \pm 1020(93.6)$ & $846 \pm 322(38.1)$ \\
\hline $\mathrm{Ce}$ & $117(83.3-170)$ & $105 \pm 12(11.4)$ & $121 \pm 20(16.2)$ \\
\hline Co & $0.695(0.170-1.28)$ & $0.250 \pm 0.068(27.1)$ & $0.810 \pm 0.120(14.8)$ \\
\hline $\mathrm{Cr}$ & $1.32(0.120-3.80)$ & $1.46 \pm 0.99(67.7)$ & $1.27 \pm 0.85(66.6)$ \\
\hline Cs & $4.68(1.02-18.5)$ & $15.1 \pm 1.7(11.1)$ & $1.89 \pm 0.35(18.6)$ \\
\hline $\mathrm{Eu}$ & $0.734(0.080-1.23)$ & $0.100 \pm 0.018(18.3)$ & $0.890 \pm 0.118(13.3)$ \\
\hline $\mathrm{Fe} \%$ & $1.05(0.83-1.44)$ & $0.970 \pm 0.099(10.3)$ & $1.07 \pm 0.15(13.7)$ \\
\hline Hf & $7.51(5.97-10.2)$ & $7.17 \pm 4.12(9.1)$ & $7.61 \pm 3.53(11.5)$ \\
\hline K\% & $3.42(0.765-6.06)$ & $3.28 \pm 0.57(17.3)$ & $3.44 \pm 1.30(37.9)$ \\
\hline La & $53.1(5.67-62.8)$ & $51.0 \pm 13.0(25.5)$ & $54.6 \pm 8.6(15.8)$ \\
\hline $\mathrm{Na} \%$ & $1.87(0.567-2.82)$ & $2.06 \pm 0.85(41.5)$ & $1.85 \pm 0.43(23.2)$ \\
\hline $\mathrm{Nd}$ & $28.1(10.1-47.9)$ & $20.3 \pm 7.0(34.7)$ & $29.7 \pm 7.5(25.1)$ \\
\hline $\mathrm{Ni}$ & $11.1(0.428-25.5)$ & 16.7 & $11.3 \pm 7.5(66.1)$ \\
\hline $\mathrm{Rb}$ & $154(58.9-270)$ & $230 \pm 21(9.0)$ & $133 \pm 24(18.1)$ \\
\hline $\mathrm{Sb}$ & $0.283(0.020-1.11)$ & $1.00 \pm 0.14(14.0)$ & $0.077 \pm 0.028$ \\
\hline SC & $2.83(0.890-4.37)$ & $1.16 \pm 0.19(16.0)$ & $3.29 \pm 0.47(14.4)$ \\
\hline Se & $2.47(0.320-3.33)$ & $2.62 \pm 0.35(13.2)$ & $2.42 \pm 0.44(18.3)$ \\
\hline Sm & $6.21(2.29-8.87)$ & $5.49 \pm 1.05(19.1)$ & $6.47 \pm 1.13(17.5)$ \\
\hline Sr & $150(22.5-758)$ & $337 \pm 257(76.2)$ & $124 \pm 96(77.3)$ \\
\hline Ta & $1.42(1.02-2.00)$ & $1.70 \pm 0.21(12.1)$ & $1.35 \pm 0.21(15.7)$ \\
\hline Th & $24.0(15.1-46.7)$ & $37.7 \pm 3.6(9.6)$ & $20.3 \pm 2.6(12.8)$ \\
\hline U & $2.36(0.570-8.61)$ & $5.91 \pm 2.10(38.9)$ & $1.43 \pm 0.65(45.3)$ \\
\hline W & $4.21(0.810-10.1)$ & $13.3 \pm 1.8(13.2)$ & $4.65 \pm 3.15(67.7)$ \\
\hline Yb & $0.037(0.020-0.060)$ & $0.054 \pm 0.005(9.4)$ & $0.032 \pm 0.007(22.9)$ \\
\hline $\mathrm{Zn}$ & $52.1(43.4-60.6)$ & $56.8 \pm 2.3(4.1)$ & $50.9 \pm 3.3(6.5)$ \\
\hline $\mathrm{Zr}$ & $2336(1541-3247)$ & $2100 \pm 252(12.0)$ & $2407 \pm 368(15.3)$ \\
\hline
\end{tabular}

Element content ( $\mu \mathrm{g} \mathrm{g}^{-1}$, except Fe, $\mathrm{K}$ and $\mathrm{K}$ expressed as\%) of obsidian artefacts (classified as group \#1 and group \#2) collected during archaeological excavations in Tuscany and analyzed by INAA.

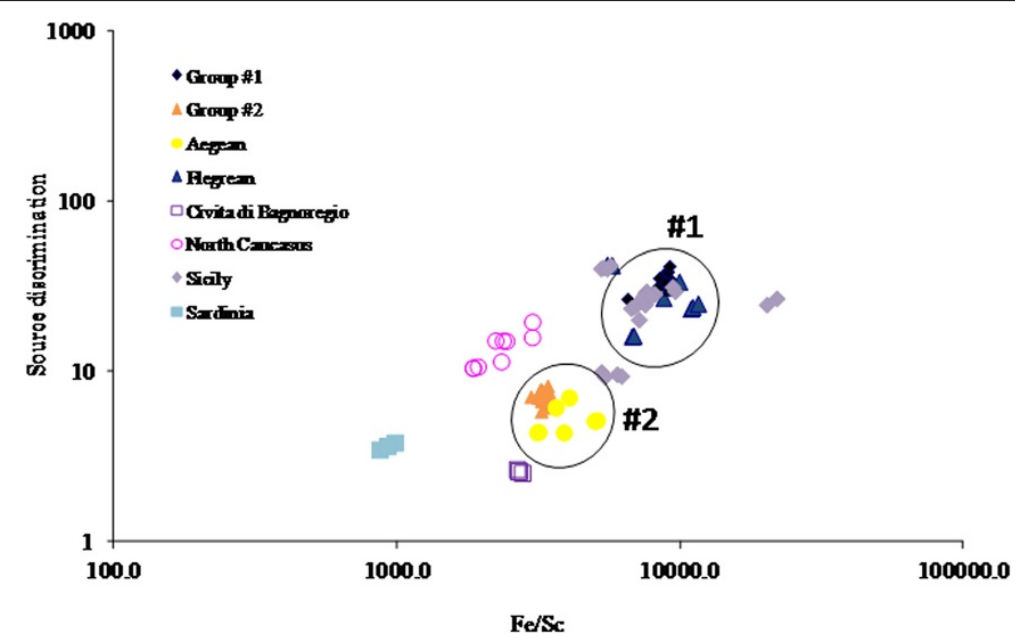

Figure 4 Source discrimination vs. Fe/Sc plot of obsidian artefacts. Multiple regression analysis: plot of the discrimination factor vs. Fe/Sc abundance ratio of the obsidian artefacts found during archaeological excavations in Tuscany. 
are important for a better knowledge of the exchange routes during the Neolithic period. The archaeologists consider importance of exchange as a factor of civilization growth. This study gives evidences about the large exchange network in the 3000 B.C.: even if Italy shows large deposits of obsidian in different areas, artefacts made by obsidian from the Aegean area and dated 5000 BP have been found in Tuscany, meaning the existence of a flow of goods towards one or the other direction in the Mediterranean are (from East to Western, and vice versa). From an archaeological point of view, it is still uncertain whether the objects were directly or indirectly received from their place of origin and we always need to view the overall picture by distinguishing among areas with different distributions of imported objects. In this way, the availability of reference obsidian samples from more areas as possible, is fundamental for both the reconstruction of the commercial trade and the knowledge of the artefact provenance.

\section{Competing interests}

The authors declare that they have no competing interests.

\section{Authors' contributions}

PA coordinated the study. PA and AR set up and performed the analytical procedure by means of INAA. PA and AR edited the text and prepared the final draft of the paper. Both authors have read and approved the final manuscript.

\section{Acknowledgements}

The authors are grateful to Dr. Nicoletta Volante (University of Siena) for having furnished the obsidian artefacts from Tuscany archaeological excavations and Dr. Francesco Guidi-Giolj (ENEA) for having collected the reference obsidian samples.

This work was supported under the grant INAIL/ DIPIA/P20L01, 2013-2015.

\section{Author details}

'DIPIA, INAIL settore Ricerca, via IV Novembre 144, Rome 1-00187, Italy.

${ }^{2}$ UTFISST, ENEA, R.C.-Casaccia, via Anguillarese 301, Rome I-00060, Italy.

Received: 24 March 2014 Accepted: 11 July 2014

Published: 24 July 2014

\section{References}

1. Renfrew R: Trade as action at a distance: questions of integration and communication. In Ancient Civilization and Trade. Edited by Sabloff JA Lamberg-Karlovsky CC. Albuquerque: University of New Mexico Press; 1975:3-60

2. Renfrew C: Alternative models for exchange and spatial distribution. In Exchange systems in Prehistory. Edited by Earle TK, Ericson JE. New York: Academic Press; 1977:71-90.

3. Tykot RH: L'esatta provenienza dell'ossidiana e i modelli di diffusione nel Mediterraneo centrale durante il Neolitico. In L'ossidiana del Monte Arci nel Mediterraneo: recupero dei valori di un territorio. Edited by Castelli P, Cauli B, Di Gregorio F, Lugliè C, Tanda G, Usai C. Ghilarza: Editore Ghilarzese; 2002:118-132.

4. Hallam BR, Warren SE, Renfrew C: Obsidian in Western Mediterranean: characterisation by Neutron Activation Analysis and Optical Emission Spectroscopy. Proc Prehist Soc 1976, 42:85-110.

5. Williams-Thorpe O: Obsidian in the Mediterranean and the Near East: a provenancing success story. Archaeometry 1995, 37:217-248.

6. Bigazzi G, Radi G: Prehistoric exploitation of obsidian for tool making in the italian Peninsula: a picture from a rich fission-track data-set. Proc XIII Inter Congr Prehistoric Protohistoric Sci 1996, 1:149-156.
7. Tykot $\mathrm{RH}$ : Obsidian procurement and distribution in the Central and Western Mediterranean. J Mediter Archaeol 1996, 9:39-82.

8. Tykot RH: New approaches to the characterization of obsidian from the Mediterranean island sources: interpreting chronological change in Neolithic Sardinia and Corsica. Mat Res Soc Symp Proc 2002, 712:||4.6.1-||4.6.15.

9. MacDonald R, Bailey DK, Sutherland DS: Oversaturated peralkaline glassy trachytes from Kenya. J Petrol 1970, 11:507-517.

10. Tykot $\mathrm{RH}$ : Chemical fingerprinting and source tracing of obsidian: the Central Mediterranean trade in black gold. Acc Chem Res 2002 35:618-627.

11. Avino P, Moioli P, Rosada A, Seccaroni C: Obsidian use in the mosaic of the St. Juvenal church, Narni (Italy): chemical characterization and origin. Heritage Sci 2013, 1:17.

12. Fornaseri M, Nalpieri L, Palmieri AM, Taddeucci A: Analysis of obsidian from the late Chalcolithic levels of Arslantepe (Malatya). Paléorient 1977, 3:231-246.

13. Capannesi G, Palmieri AM: Analisi per Attivazione Neutronica delle ossidiane della piana di Urmia. In Tra lo Zagros e l'Urmia: ricerche storiche ed archeologiche nell'Azerbaigian Iraniano. Edited by Pecorella PE, Salvini M. Rome: Edizione dell'Ateneo; 1984:387-395.

14. Djingova R, Kuleff I: Instrumental techniques for trace analysis. In Trace Elements - Their Distribution and Effects in the Environment. Edited by Markert B, Friese K. Amsterdam: Elsevier; 2000:137-185. ISBN: 0-444-50532-6.

15. Currie LA: Limits for qualitative detection and quantitative determination. Application to radiochemistry. Anal Chem 1968, 40:586-593.

16. Campanella L, Crescentini G, Avino P, Moauro A: Determination of macrominerals and trace elements in the alga Spirulina platensis. Analusis 1998, 26:210-214.

17. Avino P, Carconi PL, Lepore L, Moauro A: Nutritional and environmental properties of algal products used in healthy diet by INAA and ICP-AES. J Radioanal Nucl Chem 2000, 244:247-252.

18. Avino P, Capannesi G, Rosada A: Characterization and distribution of mineral content in fine and coarse airborne particle fractions by neutron activation analysis. Toxicol Environ Chem 2006, 88:633-647.

19. Seccaroni C, Volante N, Rosada A, Ambrosone L, Bufalo G, Avino P: Identification of provenance of obsidian samples analyzing elemental composition by INAA. J Radioanal Nucl Chem 2008, 278:277-282.

20. Avino P, Capannesi G, Rosada A: Heavy metal determination in atmospheric particulate matter by Instrumental Neutron Activation Analysis. Microchem J 2008, 88:97-106.

21. Capannesi G, Diaco L, Rosada A, Avino P: Investigation of trace and ultratrace elements of nutritional and toxicological significance in Italian potable waters by INAA. J Radioanal Nucl Chem 2008, 278:353-357.

22. Capannesi G, Rosada A, Avino P: Elemental characterization of impurities at trace and ultra-trace levels in metallurgical lead samples by INAA. Microchem J 2009, 93:188-194.

23. Avino P, Capannesi G, Diaco L, Rosada A: Multivariate analysis applied to trace and ultra-trace elements in Italian potable waters determined by INAA. Curr Anal Chem 2010, 6:26-36.

24. Capannesi G, Rosada A, Avino P: Radiochemical separation and anticompton analysis of $\mathrm{Ni}, \mathrm{Sn}, \mathrm{Te}$ and $\mathrm{Zn}$ in lead standard reference materials at ultra-trace levels. Curr Anal Chem 2010, 6:217-222.

25. Avino P, Capannesi G, Rosada A: Ultra-trace nutritional and toxicological elements in Rome and Florence drinking waters determined by Instrumental Neutron Activation Analysis. Microchem J 2011, 97:144-153.

26. Avino P, Capannesi G, Manigrasso M, Sabbioni E, Rosada A: Element assessment in whole blood, serum and urine of three italian healthy sub-populations by INAA. Microchem J 2011, 99:548-555.

27. Capannesi G, Rosada A, Manigrasso M, Avino P: Rare earth elements, thorium and uranium in ores of the North- Latium (Italy). J Radioanal NuC Chem 2012, 291:163-168

28. Avino P, Capannesi G, Renzi L, Rosada A: Instrumental neutron activation analysis and statistical approach for determining baseline values of essential and toxic elements in hairs of high school students. Ecotoxicol Environ Saf 2013, 92:206-214

29. Avino P, Capannesi G, Rosada A: Source identification of inorganic airborne particle fraction $\left(\mathrm{PM}_{10}\right)$ at ultratrace levels by means of INAA short irradiation. Environ Sci Pollut Res 2014, 21:4527-4538.

30. Gladney ES, Perrin DR, Owens JW, Knab D: Elemental concentrations in the United States Geological Survey's geochemical exploration reference samples - A review. Anal Chem 1979, 51:1557-1569. 
31. Mommsem H, Sjöberg BL: The importance of the 'best relative fit factor' when evaluating elemental concentration data of pottery demonstrated with Mycenaean sherds from Sinda, Cyprus. Archaeometry 2007, 49:359-371.

32. Tykot RH: Sourcing of Sardinian obsidian collections in the Museo Preistorico-Etnografico "Luigi Pigorini" using non-destructive portable XRF. In L'ossidiana del Monte Arci nel Mediterraneo. Nuovi apporti sulla diffusione, sui sistemi di produzione e sulla loro cronologia. Edited by Lugliè C, Editore NUR. ; 2010:85-97.

33. Aspinall A, Feather SW, Renfrew C: Neutron Activation Analysis of Aegean obsidians. Nature 1972, 237:333-334

34. Capaldi G, Gasparini P, Moauro A, Salvia E, Travaglione O: Rare earth abundances in the alkaline volcanic rocks from Campania, South Italy. Earth Planet Sci Lett 1972, 17:247-257.

35. Tykot RH, Glascock MD, Speakman RJ, Atzeni E: Obsidian subsources utilized at sites in Southern Sardinia (Italy). Mater Res Soc Symp Proc 2008, 1047:175-183.

36. Tykot RH, Ammerman AJ: New directions in central Mediterranean obsidian studies. Antiquity 1997, 71:1000-1006.

doi:10.1186/s40494-014-0016-z

Cite this article as: Avino and Rosada: Mediterranean and Near East

obsidian reference samples to establish artefacts provenance. Heritage

Science 2014 2:16.

\section{Publish with ChemistryCentral and every scientist can read your work free of charge \\ "Open access provides opportunities to our colleagues in other parts of the globe, by allowing anyone to view the content free of charge." \\ W. Jeffery Hurst, The Hershey Company. \\ - available free of charge to the entire scientific community \\ - peer reviewed and published immediately upon acceptance \\ - cited in PubMed and archived on PubMed Central \\ - yours - you keep the copyright \\ Submit your manuscript here: \\ http://www.chemistrycentral.com/manuscript/<smiles>c1ccccc1</smiles> \\ Chemistry Central}

